\title{
Analysis of Mathematical Communication Capabilities in Completing Problems in Matrix Materials Based on Solo Taxonomy
}

\author{
Sulis Setyowati, Yus Mochamad Cholily, Rizal Dian Azmi
}

\author{
Study Program of Mathematics Education, Faculty of Teacher Training and Education \\ University of Muhammadiyah Malang \\ E-mail : sulis.styowti@gmail.com
}

\begin{abstract}
The purpose of this study is to describe written mathematical communication skills based on SOLO Taxonomy for class XI MIPA students in solving problems on the matrix material. This type of research is descriptive qualitative, where the subject is 17 students of class XI MIPA. The research data collection method used a test instrument. Based on the results of data analysis, it can be concluded that there are 4 students with the criteria of written mathematical communication skills very good, 6 students with good written mathematical communication skills criteria, 7 students with Enough written mathematical communication skills criteria and students. Meanwhile, students with the written mathematical communication ability criteria are lacking. Students are in very good criteria, able to solve thelevel questions Unistructural - Relational on SOLO Taxonomy. Meanwhile, students with the criteria of good written mathematical communication skills are able to solve questions on thelevel Unistructural and thelevel Multistructural in the SOLO Taxonomy. Then students with the criteria of written mathematical communication skills are Enoughly able to solve questions on thelevel Unistructural in SOLO Taxonomy. The average written mathematical communication skills are in good criteria with an average written mathematical communication ability score of 61.95 , so that the average student is able to solve questions at the Unistructural Multistructural level in SOLO Taxonomy
\end{abstract}

Keywords: Writing Mathematical Communication, Matrix, SOLO Taxonomies

\section{INTRODUCTION}

Mathematical communication skills are the ability to express a mathematical idea in writing or orally (NCTM, 2000). Mathematical communication skills can be developed through the mathematics learning process (Hodiyanto, 2017). Mathematical communication must be a concern that focuses on learning mathematics, because through communication students are able to organize their mathematical thinking (Lanani, 2013). The important role of communication in mathematics learning, because through mathematical communication students are able to explain, express, and listen which can lead students to deeper insights into mathematics (Waluya, 2017).

Communication is needed to understand mathematical ideas correctly, one of which is communication in writing. Students who have good mathematical communication skills are able to produce a variety of understandings and find it easier to solve problems (Qohar, 2011). Research conducted by Lamonta, Tandiayuk, \& Puluhulawa (2016) states that stating communication ideas in writing is able to bring students deeper feelings. Therefore, written mathematical communication can be used as a way of conveying students' thoughts through writing (Mandasari \& Chandra, 2018). 
Students' written mathematical communication skills tend to be weak due to the lack of ability to write formulas and symbols which causes students to be lazy to discuss further mathematical concepts (Supandi, Rosvitasari, \& Kusumaningsih, 2017). Based on preliminary observations made at SMA Muhammadiyah 3 Batu, students have problems related to their written mathematical communication skills such as: 1) students are still not trained and forget when students write down the core questions as asked and known, and 2) Students still often have difficulty in writing examples or modeling or equations of a problem. Students who have good written or oral mathematical communication skills are able to produce various understandings and make it easier to solve problems (Qohar, 2011).

It is still often found that students still have difficulty solving problems (Pertiwi, 2018). One of the reasons is because the ability of students is still not used to being trained to solve problems with more complex solutions than developing a concept (Lingga, 2013). One of them is the matrix material, the matrix is a branch of algebra taught in high school. Sukayasa (2019) that students still often make mistakes in solving matrix problems. Research conducted by Krismantono (2017) and Firdaus (2019), students' mistakes that are often done, namely lies in the misunderstanding of the concept of rows and columns in the matrix, errors in multiplication operations between rows and columns, formula errors to determine the inverse of the $3 \times 3$ order matrix, errors in working on determinants and inverse matrices, as good as errors in calculating the value of the matrix, resulting in less than optimal student work and decreased student achievement.

Students have different levels and abilities when solving a problem (Azizah, 2015). Therefore, the way to recognize students' abilities when solving problems is the SOLO Taxonomy. Supported by research Biggs (1978) states that SOLO Taxonomy can be used to determine the quality of student responses to an assignment. SOLO stands for the word "Structure of the Observed Learning Outcome" which means the structure of the observed learning outcomes. The classification of students' abilities to problems in SOLO Taxonomy consists of five different levels and is hierarchical in nature, namely Prestructural, Unistructural, Multistructural, Relational, and Extended Abstrack (Putri, 2013). According to Tampi, Subanji, \& Sisworo (2017), a theory known as the Structure of the Observed Learning Outcome (SOLO) is based on student responses to a problem.

Based on the description above, the researcher will conduct research with the title "analysis of mathematical communication skills in solving problems on the matrix material based on SOLO Taxonomy". The purpose of this research is to describe the mathematical communication skills in solving problems on the matrix material based on the SOLO Taxonomy. The analysis of the results of this study is expected to be useful in learning mathematics and be able to become a benchmark in improving and maintaining students' mathematical communication.

\section{RESEARCH METHOD}

This research is a qualitative-descriptive research. This study describes the mathematical communication skills of students in solving a matrix problem based on SOLO Taxonomy through tests or giving questions. This research was carried out through 3 stages, namely (1) preparation; (2) implementation and; (3) End. The study was conducted at SMA Muhammadiyah 3 Batu in the even semester.The research subjects 
were students of class XI MIPA Muhammadiyah 3 Batu High School in the academic year 2019/2020.

The instruments used in this study were the researchers themselves, written test sheets, and interview guidelines. Test sheets are prepared based on SOLO Taxonomy Superitem Test. Superitem contains a problem and four different levels of difficulty. Items that represent the four levels are defined by SOLO's taxonomy which includes Unistructural, Multistructural, Relational, and Extended Abstract. So, with this Superitem, the correct response or answer indicates students' mathematical communication skills at each level based on SOLO Taxonomy. Before the test sheet is tested on students, the questions are checked for validity and validated by lecturers and teachers. Furthermore, the results of these tests were analyzed by students' written mathematical communication skills in terms of written mathematical communication skills indicators including;Write down the core questions that are known and asked from the questions given; (2) Finding an idea by writing an example / modeling and the form of the equation; (3) Write a formula to draw up a settlement plan or completion strategy to get a solution; (4) Determine strategies or resolve problems in the form of writing or drawing properly and correctly and able; (5)make conclusions using your own language in the form of writing from the results of problem solving. While the interview guidelines are adjusted to the indicators that have been made, namely: 1) students are able to mention information obtained from questions, 2) students know the methods used to solve problems; 3) students are able to explain the methods used to solve problems and; 4) students are able to deduce from the answers they get. The sincere test questions were adapted from (Jamil, 2017) used in this study as follows.

\section{WRITING TEST PROBLEMS}

A factory produces footwear such as shoes and sandals located in Malang. The factory produces two kinds of footwear only for children and adolescents. In 2020 the factory produced 50 pairs of shoes for children and 40 pairs of shoes for teenagers. As for the production of sandals for children - as many as 60 pairs and 50 pairs for teenagers.

\section{Unistructural Level}

Form a matrix "M", where $\mathrm{M}$ is a production matrix with the first row showing the number of shoes and the second row showing the number of sandals and the first column showing for children and the second column showing for teens!

2. Multistructural Level

Determine much of the production of sandals and shoes in matrix form by 2021 if shoe production increases by 25 pairs and production of sandals is five times the production of shoes!

3. Relational level

If the factory has a target for each year, production of shoes increases by 25 pairs and sandals production is five times the production of shoes. Form a new formula in the form of a matrix that shows how many shoes and how many sandals are produced! 
4. Extended Abstract Level

"In 2020, the factory will get 25,000,000 million of shoes and 30,500,000 million of sandals". Develop a mathematical problem from the story and then solve it as before using the matrix!

Data collection in this study begins with giving individual problem solving tests to research subjectsand continued with the interview according to the interview guidelines. Furthermore the data analysis technique is a continuation of the data collection technique. Data analysis technique aims to answer the problem formulation in a study that has 4 aspects in qualitative data analysis, namely: 1) data collection by conducting written tests of 4 questions and interviews with students; 2) data reduction by categorizing into 4 categories of written mathematical communication skillsbased on assessment criteria which already contain indicators of written mathematical communication skills and levels in the SOLO Taxonomy. FollowingThe written mathematical communication ability criteria can be seen in table 1 ; 3) the presentation of data obtained from the results of written test answers and interviews conducted by students will then be described in the form of sentences or descriptions, and; 4) drawing conclusions containing a brief description of the results of the analysis of mathematical communication skills based on SOLO Taxonomy.

Table 1. Criteria for Written Mathematical Communication Skills

\begin{tabular}{lcc}
\hline No. & Score & $\begin{array}{c}\text { Criteria for Students' Mathematical } \\
\text { Communication Skills }\end{array}$ \\
\hline 1 & $76<$ nilai $\leq 100$ & Very good \\
2 & $51<$ nilai $\leq 75$ & Good \\
3 & $26<$ nilai $\leq 50$ & Enough \\
4 & $0<$ nilai $\leq 25$ & Less \\
\hline
\end{tabular}

\section{RESULT AND DISCUSSION}

This study examines written mathematical communication skills based on SOLO Taxonomy. The study was conducted at Muhammadiyah 3 Batu High School. The study was conducted in MIPA XI class with 17 students as research subjects who had taken matrix material in odd semester. The study was conducted by administering tests containing questions in accordance with SOLO Taxonomy indicators that must be completed by students who numbered 4 questions. The test was conducted to determine students' mathematical communication skills based on written mathematical communication indicators.

Students' written test results are divided into 4 written mathematical communication ability criteria including those with very good, good, enough, and less criteria. As many as 4 students with written mathematical communication ability criteria are very good. A total of 6 students with good written mathematical communication skills. Then, as many as 7 students with enough written mathematical communication ability criteria and as many as 0 students with poor written mathematical communication ability 
criteria or no students were in less criteria. Thus, the average results of the XI MIPA grade $\mathrm{X}$ Muhammadiyah 3 Batu high school written test results show that mathematical communication skills written on the matrix material are included in both criteria with an average score of 61.95. This can be seen in Table 2 .

Table 2. Criteria for Students' Mathematical Writing Ability Communication

\begin{tabular}{cccc}
\hline No & Criteria & Frequency & STUDENT'S NAME \\
\hline 1 & Very good & 4 & SA, EM, N, ABG \\
2 & Good & 6 & MM, AUH, JD, NA, MA, AB \\
3 & Enough & 7 & ALB, BR, S, RTS, MAH, NS, ZRS \\
4 & & 0 & - \\
Total Student Grades & & $\mathbf{1 0 5 3 . 1 3}$ \\
\multicolumn{2}{r}{ Average } & & $\mathbf{6 1 . 9 5}$ \\
& Criteria & & GOOD \\
\hline
\end{tabular}

\section{A. Students' Written Mathematical Communication Skills Very Good}

Written mathematical communication skills are very good and have written mathematical communication scores ranging from more than 75 to 100. After carrying out a matrix problem solving analysis, there are 4 students who occupy very good criteria, namely SA, EM, N, and ABG.

The results of the work of SA, EM, ABG and $\mathrm{N}$ students were able to write down the core questions that were known and asked at the unistructural level -level questions relational. However, at the level of extended abstract, SA, EM, ABG and N students were not precise in writing down the core questions that were known and asked about the questions given. The second indicator is that students are able to find ideas by writing down the example / modeling and the form of the equation. SA and ABG students are less precise on the second indicator at the multistructural level. At the level extended abstract, $\mathrm{ABG}$ and $\mathrm{N}$ students are less precise on the second indicator. Then, in the third indicator, students write a formula to develop a completion plan or a settlement strategy to find a solution. Students. SA, EM, ABG and N are able to complete up to the level relational. However, at the level of extended abstract, $\mathrm{ABG}, \mathrm{N}$ and EM students were not precise in writing formulas to develop a settlement plan or a settlement strategy to find a solution. The same thing is also found in the fourth indicator where students determine strategies or problem solving in writing or pictures properly and correctly. SA, EM, ABG and N students are able to complete up to the level relational. At the level extended abstract, $\mathrm{ABG}, \mathrm{N}$ and $\mathrm{EM}$ students are less precise in the fourth indicator. For the fifth indicator, students make conclusions using their own language in the form of writing from the results of problem solving. There is one student, namely SA students at the level unistructural who did not write their conclusions. At the level extended abstract,students were ABG, $\mathrm{N}$ and $\mathrm{EM}$ not precise in writing conclusions. 
Students with very good criteria are able to work up to the level Relational in SOLO Taxonomy. This means that students are able to use all the information and determine extra information in the problem that can be used to find a final solution. However, there are students on very good criteria trying to complete at the level Extended Abstract according to the written communication ability indicators. Students who are able to solve problems at the level are Extended Abstractable to work on questions at the levels Unistructural, Multistructural and Relational. Students who have not been able to solve problems at the level are Extended Abstract due to not being able to use general abstract principles from the questions and build hypotheses that are derived from the information on the questions.

Based on the results of tests and interviews with students with very good criteria, it shows that errors in student work on test questions are caused by:

a) Students have difficulty understanding and reading information on questions.

b) Students are not used to writing what they know and ask.

c) Students are lacking in managing strategies in finding solutions.

d) Students are rushed in working on the questions afraid because time runs out, so students tend not to reexamine answer

\section{B. Students' Written Mathematical Communication Skills Good}

Good written mathematical communication skills have written mathematical communication scores ranging from more than 50 to 75 . After conducting matrix problem solving analysis, there were 6 students who occupied good criteria, namely MM, AUH, JD, NA, MA, and AB.

The results of the student work on the indicators wrote down the core questions that were known and asked, MM, AUH, JD, NA, MA, and AB students were able to complete at the unistructural level - the multistructural level. While the first indicator at the relational and extended abstract level of students MM, AUH, JD, NA, MA, and AB was not correct and correct in completing it. The indicator finds ideas by writing down the example / modeling as well as the form of the equation MM, AUH, JD, NA, MA, and AB students are able to complete at the unistructural level - the multistructural level. at the relational and extended abstract levels students of MM, AUH, JD, NA, MA, and AB have not been able to write the examples / modeling or the form of the equation. the indicator writes a formula for preparing a completion plan or a settlement strategy to get a solution. At the level Relational, there are several students with good criteria who have not been able to complete correctly, one of which is the work done by MM students. The fourth problem with the level Extended Abstract, all students with good criteria have not been able to complete correctly so that they cannot meet the indicators of their written mathematical communication skills.

Students with good criteria are able to solve questions at the level Multistructural in Taxonomy SOLO. Even though at this level there are some students who are still not precise in their written mathematical communication skills. At the level of multistructural, 
students are able to use more than two pieces of information on a problem to find a solution. Students at the level are Multistructural only able to solve questions at the level Unistructural. At the level Unistructural, students have the ability to use information contained in a problem to get a solution. Students with the criteria of good written mathematical communication skills have not been able to solve problems at the level Relational. Even though at the level Relational there are some students who have done it even though they do not meet the indicators of their written mathematical communication skills, they are said to have not been able to finish correctly. In the level problem, the Extended Abstract four students were not able to use general principles abstract from problems and build hypotheses that are derived from information to solve problems.

Based on the test results and the results of interviews with students with good criteria, it shows that errors in student work on test questions are caused by:

a) Students have difficulty understanding the information on questions

b) Students are not used to writing what they know and ask

c) Students are less trained to work on similar questions so that students are not able to understand the questions givenStudents are less trained

d) Lack of students' training in finding strategies to sample and model the information on the questions

\section{Students' Written Mathematical Communication Skills Enough}

Mathematical communication skills with nough criteria have written mathematical communication values ranging from more than 25 to 50 . After analyzing matrix problem solving, there are 7 students who are in the criteria of Enough delivery between ALB, BR, S, RTS, MAH, NS, and ZRS.

Students with enough criteria are able to work on Unistructural level problems. At the Multistructural level there are two students namely ALB and RTS which is not quite right on the second and third indicators. In the first indicator, one of the students, ALB, does notWrite down the core of the question that is known and asked from the problem incorrectly. The second indicator is mfind ideas by writing down examples / modeling and the form of equations and the third indicator writing formulas for developing a solution plan or completion strategy to find a solution.But there are some students who try to work on Relational level problems, one of them is NS students. Then, a matter of the level of Extended Abstrac studentsALB, BR, S, RTS, MAH, NS, and ZRS did not complete at all so that the indicators of communication skills he wrote was not met at all.

Students with enough criteria are able to complete up to the level Unistructural at SOLO Taxonomy and able to meet all indicators of mathematical communication skills. At the level Unistructural, students are only able to use the information contained in the problem to find a solution. Meanwhile, at the level of questions multistructural, there are still students who are still inaccurate in the process so that some indicators of their mathematical communication skills cannot be met accurately and correctly. At the level, relational students with the criteria of written mathematical communication skills are still 
not able to finish correctly so that these students have not been able to solve using all the information and determine extra information in problems that can be used to enable final solutions. Errors tend to be problems with the level Extended Abstract because all students on the criteria for written communication skills do not complete at all according to the indicators of their written mathematical communication skills, so that these students have not been able to use general abstract principles from problems and build hypotheses that are derived from information on questions to solve problems.

Based on the test results and the results of interviews with students with enough criteria indicate that errors in the workmanship of students on test questions caused by:

a) Students have difficulty understanding and reading information on questions

b) Students are not used to writing what they know and ask

c) Students are not able to find strategies to find solutions

d) Lack of students' ability to interpret data

e) Students are less trained to work on similar questions so that students are unable to answer the questions given

f) Lack of students' training in finding strategies to sample and model the information in question

\section{Students' Written Mathematical Communication Skills Less}

The ability to write mathematical communication with the criteria less the value of written mathematical communication ranging from more than 0 to 25 . After analyzing the matrix problem solving, there are no students who are at the less level.

Based on the results of the analysis that the average student is in the criteria of good mathematical communication skills so that students are able to solve the level questions Unistructural and Multistructural on SOLO Taxonomy. Students with written mathematical communication ability criteria are very good at being able to work on problems at the Unistructural, Multistructural and Relational levels. Students with Very Good written communication skills are able to complete according to indicators of written mathematical communication skills. At the level of Extended Abstract, students with very good criteria are still not able to finish correctly so that their written communication skills are also less. Students with written mathematical communication ability criteria are very good at the Relational level, so students are able to use all the information and determine extra information in the problem that can be used to find a final solution. Research conducted by Putri (2013) states that students with high abilities in SOLO Taxonomy are able to finish up to the level of Unistructural, Multistructural and Relational. In line with research conducted by Romlah (2017), students with high mathematical abilities then their mathematical communication skills are very good written. So students with high abilities have Very Good mathematical communication skills and are able to solve problems up to a high level in SOLO Taxonomy.

Students with good written mathematical communication skills are able to work on problems at a level Unistructural and Multistructural. Research conducted by Putri 
(2013) also stated that students with moderate ability in SOLO Tasksonomics were able to finish up to the Unistructural and Multistructural stages. Students with good written mathematical communication ability criteria able to complete in accordance with indicators of mathematical communication skills written. Research conducted byMandasari \& Chandra (2018) that students with good criteria have mathematical abilities while solving problems according to indicators of mathematical communication written ability. So students with mathematical abilities are having mathematical communication skills with good criteria and are able to solve problems until Unistructural and Multistructural on SOLO Taxonomy .

Students with written mathematical communication ability criteria are quite capable of working on problems at a level Unistructural . Which is at the Unistructural level where students are only capableuse the information contained in the problem to find a solution. Mathematical communication skills written in terms of: a) students are able to write the core of the questions that are known and asked from the questions given, $b$ ) students are able to find ideas by writing examples / modeling and the form of equations, c) students are able to write formulas to draw up plans for completion or completion strategy to find a solution, d) students are able to determine the strategy or solution of problems in written or picture form properly and correctly and able, e) students are capable of make conclusions using their own language in the form of writing from the results of problem solving. in research conducted by Putri (2013) states that students with low criteria are able to finish up to the Unistructural level. Students with written mathematical communication criteria have quite a low ability. In line with researchLutfianannisak \& Sholihah (2018) students with written mathematical communication skills have quite a low ability. So it was concluded that students' written mathematical communication skills with Enough criteria had low mathematical ability andstudents with low ability are able to solve level questions Unistructural on SOLO Taxonomy.

Research conducted by Romlah (2017) states that students with high mathematical abilities then written mathematical communication skills are in very good criteria, in line with research conducted by Putri (2013)that students with high ability on SOLO Taxonomy are able to solve problems at the Unistructural - Relational level. So it can be concluded that students with Very Good written communication skills criteria, the level of SOLO Taxonomy is at the Unistructural - Relational level. In contrast to the research conducted byMandasari \& Chandra (2018)that students with good mathematical communication criteria have students having moderate mathematical abilities. Research conducted byPutri (2013) also stated that students with moderate abilities in SOLO Taxonomy were able to finish up to the Unistructural and Multistructural stages. So it can also be concluded that students with good written communication skills criteria then the level of SOLO Taxonomy is at the Unistructural level and Multistructural level. 


\section{CONCLUSION}

Referring to the results of the research that has been obtained, the researcher obtained the following conclusions. Students' written mathematical communication skills based on SOLO Taxonomy are divided into 4 written mathematical communication skills criteria, which are Very Good mathematical communication skills criteria, good mathematical communication skills criteria, written mathematical communication skills criteria are Enough, and mathematical communication skills criteria are less. A total of 4 students with very good mathematical communication ability criteria are very good, 6 students with good mathematical communication ability criteria, 7 students with Enough mathematical communication ability criteria and students. Whereas for students with written mathematical communication skills criteriaLessnone. Students are in very good criteria, able to solve Unistructural - Relational level problems in SOLO Taxonomy. Meanwhile, students with good written mathematical communication skills are able to solve Unistructural level questions and Multistructural levels in SOLO Taxonomy. Then students with written mathematical communication ability criteria are quite capable of solving Unistructural level problems in SOLO Taxonomy

\section{REFERENCES}

Azizah, F. R. (2015). Analisis Kemampuan Pemecahan Masalah Matematika Berdasarkan Taksonomi Solo Pada Sub Pokok Bahasan Balok Siswa Kelas Viii-H Smp. 1-241.

Biggs, John;Kevin Collis. (1978). Evaluating The Quality Of Learning The Solo Taxonomy (Structure Of The Observed Learning Outcome). Analytical Chemistry, 50(3), 394a-394a. Https://Doi.Org/10.1021/Ac50025a791

Firdaus. (2019). Analisis Kesalahan Mahasiswa Dalam Menyelesaikan Soal Aljabar Linier Pada. 2(1).

Hodiyanto, H. (2017). Kemampuan Komunikasi Matematis Dalam Pembelajaran Matematika. 7(1).

Jamil, A. F. (2017). Peningkatan Level Berpikir Aljabar Siswa Berdasarkan Taksonomi Solo Pada Materi Persamaan Linier Melalui Pemberian Scaffolding. Jurnal Ilmiah Mandala Education, 3(1), 1-13. Https://Doi.Org/10.1017/Cbo9781107415324.004

Krismantono, R. R. (2017). Analisis Kesalahan Dalam Menyelesaikan Soal Matematika. 177-181.

Lamonta, P. A., Tandiayuk, M. B., \& Puluhulawa, I. (2016). Analisis Kemampuan

Komunikasi Matematis Siswa Kelas Viii Smp Negeri 19 Palu Dalam Memahami

Volume Balok. Jurnal Elektronik Pendidikan Matematika Tadulako, 03(04), 464477.

Lanani, K. (2013). Belajar Berkomunikasi Dan Komunikasi Untuk Belajar Dalam $\begin{array}{llll}\text { Pembelajaran } \quad \text { Matematika. Infinity Journal, } & \text { 2(1), }\end{array}$ Https://Doi.Org/10.22460/Infinity.V2i1.21

Lingga, A. ; W. S. (2013). Pengaruh Kemampuan Berpikir Aljabar Terhadap Kemampuan Pemecahan Masalah Matematika (Studi Kasus Di Kelas Viii Smp Negeri 1 Kaliwedi Kabupaten Cirebon) Alif.

Lutfianannisak, L., \& Sholihah, U. (2018). Kemampuan Komunikasi Matematis Siswa 
Dalam Menyelesaikan Soal Materi Komposisi Fungsi Ditinjau Dari Kemampuan Matematika. Jurnal Tadris Matematika, Https://Doi.Org/10.21274/Jtm.2018.1.1.1-8

Mandasari, R., \& Chandra, T. D. (2018). Kemampuan Komunikasi Matematis Tulis Siswa Smp Dalam Menyelesaikan Masalah. Jurnal Pendidikan, 3(1), 838-850.

Nctm. (2000). Principle And Standards For School Mathematics.

Pertiwi, W. (2018). Analisis Kemampuan Berpikir Kritis Matematis Peserta Didik Smk Pada Materi Matriks. 2(C), 821-831.

Putri, L. F.; J. T. M. (2013). Identifikasi Kemampuan Matematika Siswa Dalam Memecahkan Masalah Aljabar Di Kelas Viii Berdasarkan Taksonomi Solo. Mathedunesa, 2(1), 29-30.

Qohar, A. (2011). Mathematical Communication: What And How To Develop It In Mathematics Learning? International Seminar And The Fourth National Conference On Mathematics Education. Department Of Mathematics Education, Yogyakarta State University., 1-12. Retrieved From Https://Core.Ac.Uk/Download/Pdf/11058861.Pdf

Romlah, S. ; G. K. ; W. S. (2017). Analisis Kemampuan Komunikasi Matematik Siswa Smp. Ikip Siliwangi Bandung, 01(02), 37-46.

Sukayasa, F. G. S. (2019). Profil Kesalahan Siswa Dalam Menyelesaikan Soal Matriks Berdasarkan Jenis Kelamin Di.

Supandi, Rosvitasari, D. N., \& Kusumaningsih, W. (2017). Peningkatan Kemampuan Komunikasi Tertulis Matematis Melalui Strategi Think-Talk-Write. Jurnal Kependidikan, 1(2), 227-239.

Tampi, W., Subanji, , \& Sisworo, ,. (2017). Proses Metakognisi Siswa Dalam Pemecahan Masalah Aljabar Berdasarkan Taksonomi Solo. Jurnal Matematika, 7(1), 30. Https://Doi.Org/10.24843/Jmat.2017.V07.I01.P80

Waluya, P.; B. (2017). Analysis Mathematical Communication Skills Students In The Matter Algebra Based Nctm. Iosr Journal Of Mathematics, 13(01), 60-66. Https://Doi.Org/10.9790/5728-1301056066 